ISSN : $2302-1590$

E-ISSN: $2460-190 \mathrm{X}$

\title{
ECONOMICA
}

Journal of Economic and Economic Education Vol.2 No.2 (85 - 98)

\section{PENGARUH LINGKUNGAN KELUARGA DAN MOTIVASI BELAJAR SISWA TERHADAP HASIL BELAJAR AKUNTANSI SISWA KELAS X SMK NEGERI 1 SOLOK SELATAN}

\author{
Husnan Jamil \\ Mahasiswa Program Studi Pendidikan Ekonomi STKIP- PGRI Sumbar \\ Jl. Gunung Pangilun No.1, Padang Sumatera Barat \\ Email: husnan.11@yahoo.com \\ Fefri Indra Azra \\ Dosen Fakultas Ekonomi Universitas Negeri Padang dan \\ Dosen Program Studi Pendidikan Ekonomi STKIP- PGRI Sumbar \\ Jl. Gunung Pangilun No.1, Padang Sumatera Barat \\ Email: fefri.azra@yahoo.com
}

Submited: 2014.02.23 Reviewed: 2014.04.12 Accepted: 2014.04.12

http://dx.doi.org/10.22202/economica.2014.v2.i2.221

\begin{abstract}
The research was conducted at SMK Negeri 1 South Solok the influence of family environment and students' motivation towards learning outcomes of accounting students of class X of SMK Negeri 1 South Solok. The purpose of this study is to obtain empirical evidence about the influence of family environment and students' motivation towards learning outcomes of accounting students of class X of SMK Negeri 1 South Solok. Family environment data (X1) and motivation (X2) is obtained from the results of the questionnaire or questionnaires while accounting student learning outcomes data $(Y)$ is obtained from the documentation of the value end of the semester.The results showed that: 1. Family environment and a positive significant effect on learning outcomes of accounting students of class X of SMK Negeri 1 South Solok, 2. Motivation to study significant and positive impact on learning outcomes of accounting students of class X of SMK Negeri 1 South Solok, 3. Family environment and student motivation are jointly significant effect on learning outcomes of accounting students of class X of SMK Negeri 1 South Solok. Based on these results, it is suggested that students, parents, teachers and the school for more attention to the family environment and students' motivation in the learning process in an attempt to further optimize the learning outcomes of accounting students of class X of SMK Negeri 1 South Solok.
\end{abstract}

\footnotetext{
Abstrak

Penelitian ini dilaksanakan pada SMK Negeri 1 Solok Selatan untuk melihat pengaruh lingkungan keluarga dan motivasi siswa terhadap hasil belajar akuntansi siswa kelas X SMK Negeri 1 Solok Selatan. Tujuan penelitian ini adalah untuk memperoleh hasil empiris tentang pengaruh lingkungan keluarga dan motivasi siswa terhadap hasil belajar akuntansi siswa kelas X SMK Negeri 1 Solok Selatan. Data Lingkungan Keluarga ( X1) dan motivasi (X2) diperoleh dari hasil daftar pertanyaan atau kuesioner ( Y) diperoleh dari dokumentasi nilai akhir semester.Hasil penelitian menunjukkan bahwa: 1. Lingkungan Keluarga berpengaruh positif dan signifikan terhadap hasil belajar akuntansi siswa kelas X SMK Negeri 1 Solok Selatan, 2. Motivasi belajar berpengaruh positif dan signifikan terhadap hasil belajar akuntansi siswa kelas X SMK Negeri 1 Solok Selatan, 3. Lingkungan Keluarga Dan Motivasi Siswa secara bersama-sama berpengaruh positif dan signifikan terhadap hasil belajar akuntansi siswa kelas X SMK Negeri 1 Solok Selatan. Berdasarkan penelitian ini dapat disarankan orang tua, dan para guru dan pihak sekolah untuk lebih perhatian kepada lingkungan keluarga dan memotivasi siswa dalamproses belajar mengajar.

Keywords : Family Environment, Motivation, Learning Outcomes
} 


\section{PENDAHULUAN}

Semakin pesatnya perkembangan masyarakat Indonesia di era globalisasi ini sehingga banyaknya generasi muda yang menuntut untuk semakin maju, responsif dan memiliki mobilitas tinggi dalam berfikir maupun bertindak, sehingga dapat berpartisipasi aktif dalam proses reformasi dan globalisasi. Berbagai kemajuan dalam peradaban manusia sampai saat ini tidak pernah lepas dari dunia pendidikan, karena pendidikan berfungsi untuk meningkatkan kualitas manusia, baik individu maupun kelompok, baik jasmani dan rohani maupun kematangan dalam berfikir. Hal ini tentunya beralasan, karena melalui pendidikan dapat tercapai output sumber daya manusia yang mampu mengoptimalkan berbagai sumber daya yang ada dimanfaatkan dalam kehidupan.

Kualitas pendidikan yang baik terletak pada sumber daya manusia yang baik pula, dimana semua pihak yang terlibat dalam proses pendidikan harus berusaha mengembangkan potensi yang dimiliki, ini sesuai dengan dasar, fungsi dan tujuan pendidikan nasional di dalam UU No. 20 Tahun 2003 pasal 3 yang berbunyi:

Pendidikan Nasional bertujuan mengembangkan kemampuan dan membentuk watak serta peradaban bangsa yang bermartabat dalam rangka mencerdaskan bangsa, bertujuan untuk berkembangnya potensi peserta didik agar menjadi manusia yang beriman dan bertakwa kepada Tuhan Yang Maha Esa, berakhlak mulia, sehat, berilmu, cakap, kreatif, mandiri dan menjadi warga negara yang demokratis serta bertanggung jawab.

Dengan adanya undang-undang tersebut, maka dari waktu ke waktu bidang pendidikan haruslah tetap menjadi prioritas dan menjadi orientasi untuk diusahakan perwujudan sarana dan prasarananya terutama untuk sekolah. Salah satu tugas pokok sekolah adalah menyiapkan siswa agar dapat mencapai perkembangannya secara optimal. Seorang siswa dikatakan telah mencapai perkembangannya secara optimal apabila siswa dapat memperoleh pendidikan dan hasil belajar, kemampuan dan minat yang dimilikinya.

Pendidikan adalah usaha sadar untuk menumbuh kembangkan potensi sumber daya manusia melalui kegiatan pengajaran dan mewujudkan peningkatan kualitas pendidikan melalui perbaikan kurikulum, sarana prasarana, bahkan pengembangan dan pengadaan materi pelajaran serta pendidikan bagi guru dan tenaga pendidik lainnya. Sistem pendidikan nasional merupakan keseluruhan komponen pendidikan yang saling terikat secara terpadu untuk mencapai hasil tujuan dari pendidikan nasional. Tujuan pendidikan tersebut dapat dilakukan dengan cara meningkatkan hasil belajar sebagai suatu pencapaian dari proses pembelajaran akan menunjukkan atau mengambarkan seberapa berhasil proses belajar yang telah terjadi, juga mengambarkan keberhasilan siswa dalam mencapai tujuan pembelajaran yang dinyatakan dengan angka-angka atau nilai.

Dalam dunia pendidikan, menilai merupakan salah satu kegiatan yang tidak dapat ditinggalkan. Menilai merupakan salah satu proses belajar dan mengajar. Kegiatan menilai bidang akademik di sekolah dapat dilakukan dengan adanya tugas individu, ulangan dan ujian. Dengan kegiatan tersebut dapat diketahui sejauh mana hasil belajar seseorang siswa dalam mata pelajaran akuntansi.

Berdasarkan hasil observasi awal yang penulis lakukan di SMK Negeri 1 Solok Selatan, penulis mendapatkan data nilai mata pelajaran akuntansi yang masih di bawah KKM (kriteria ketuntasan minimum) yang ditetapkan oleh sekolah yaitu 70. Hal ini dapat terlihat dari rata-rata nilai ulangan kelas $X$ semester genap tahun ajaran 2012/2013 pada tabel berikut: 
Tabel 1. Rata-rata Nilai Ulangan Semester 2 TP 2012-2013 Kelas X SMK Negeri 1 Solok Selatan

\begin{tabular}{|c|c|c|c|c|c|c|c|c|}
\hline \multirow[t]{2}{*}{ No } & \multirow{2}{*}{ Kelas } & \multirow{2}{*}{$\begin{array}{c}\text { Nilai } \\
\text { Rata- } \\
\text { rata }\end{array}$} & \multirow{2}{*}{$\begin{array}{c}\mathbf{K K} \\
\mathbf{M}\end{array}$} & \multirow{2}{*}{$\begin{array}{l}\text { Jumlah } \\
\text { Siswa }\end{array}$} & \multicolumn{2}{|c|}{$\begin{array}{c}\text { Siswa yang } \\
\text { tuntas }\end{array}$} & \multicolumn{2}{|c|}{$\begin{array}{c}\text { Siswa yang tidak } \\
\text { tuntas }\end{array}$} \\
\hline & & & & & Jumlah & $\%$ & Jumlah & $\%$ \\
\hline 1 & X PM & 53,4 & 70 & 35 & 7 & 20,00 & 28 & 80,00 \\
\hline 2 & X AP & 63,03 & 70 & 33 & 10 & 30,30 & 23 & 69,70 \\
\hline 3 & X PH & 71,52 & 70 & 33 & 23 & 69,70 & 10 & 30,30 \\
\hline
\end{tabular}

Sumber: Guru mata pelajaran akuntansi

Berdasarkan Tabel 1 di atas, diperoleh informasi bahwa jumlah persentasi ketuntasan siswa pada nilai ulangan semester 2 berkisar antara 20,00$69,70 \%$. Siswa dikatakan tuntas secara individu jika mencapai nilai kriteria ketuntasan minimum (KKM) yang ditetapkan sekolah, KKM yang ditetapkan oleh sekolah untuk mata pelajaran akuntansi sama di setiap kelas yaitu 70 . Berdasarkan tabel di atas, dapat dilihat belum semua kelas atau siswa mencapai rata-rata di atas KKM, dilihat dari 3 lokal yang ada, hanya X Akomodasi Perhotelan yang rata-ratanya di atas KKM, tetapi kelas $X$ Pemasaran dan $\mathrm{X}$ Administrasi Perkantoran yang rata-ratanya di bawah KKM.

Dilihat dari KKM ketiga kelas, maka kelas X Akomodasi Perhotelan yang tinggi nilai akuntansinya, dimana siswa yang tuntas $69,70 \%$ dengan jumlah siswa 23 orang dan siswa yang tidak tuntas $30,30 \%$ dengan jumlah siswa 10 orang. Sedangkan lokal atau kelas X Pemasaran yang paling rendah nilai akuntansinya, dimana siswa yang tuntas $20 \%$ dengan jumlah siswa 7 orang dan siswa yang tidak tuntas $80 \%$ dengan jumlah siswa 28 orang.

Berdasarkan hasil wawancara yang dilakukan terhadap beberapa orang siswa di dapat hasil bahwa ketika mereka berada dirumah, orang tua kurang memantau dan memperhatikan ataupun menanyakan apa saja yang mereka butuhkan untuk menunjang pembelajaran dan mendapatkan hasil belajar yang baik. Dan dari segi guru, pada awal pebelajaran jarang memberikan motivasi baik saat pembelajaran dimulai ataupun sesudah pembelajaran selesai.
Kondisi demikian tentu banyak faktor yang mempengaruhinya. Secara umum, hasil belajar dipengaruhi oleh faktor yang berasal dari dalam diri siswa (internal) dan faktor yang berasal dari luar didi siswa (eksternal). Dalyono (2007:5560) mengemukakan faktor-faktor yang menentukan pencapaian hasil belajar yaitu:

1. Faktor internal (yang berasal dari dalam diri) yang meliputi kesehatan, inteligensi dan bakat, minat dan motivasi, dan cara belajar.

2. Faktor eksternal (yang berasal dari luar diri) yang meliputi keluarga, sekolah, masyarakat, dan lingkungan sekitar.

Mengingat banyaknya faktor yang menentukan hasil belajar siswa, maka fokus kajian dalam penelitian ini yang diduga berpengaruh terhadap hasil belajar siswa kelas X SMK Negeri 1 Solok Selatan adalah lingkungan keluarga sebagai faktor eksternal dan motivasi belajar sebagai faktor internal.

Lingkungan keluarga merupakan tempat seseorang anak di didik dari awal sejak ia lahir dan perkembangannya akan selalu dipengaruhi oleh bagaimana lingkungan keluarga tersebut mempengaruhi psikologisnya, karena dari lingkungan keluarga pula mereka akan belajar pada lingkungan yang lebih besar yaitu lingkungan masyarakat dan lingkungan sekolah tempat seseorang belajar. Hal ini sesuai dengan pernyataan Sutjipto Wirosidjojo (dalam Slameto, 2003:61) mengatakan bahwa: 
Keluarga adalah lembaga pendidikan yang pertama dan utama. Keluarga yang sehat besar artinya untuk pendidikan dalam ukuran kecil, tetapi bersifat menentukan untuk pendidikan dalam ukuran besar yaitu pendidikan bangsa, negara dan dunia.

Sedangkan menurut Djamarah(2004:24) pendidikan dalam keluarga memiliki nilai strategis dalam membentuk kepribadian anak. Sejak kecil anak sudah mendapat pendidikan dari kedua orang tuanya melalui keteladanan dan kebiasaan hidup sehari-hari dalam keluarga. Baik tidaknya keteladanan yang diberikan dan bagaimana kebiasaan hidup orang tua sehari-hari dalam keluarga akan mempengaruhi perkembangan jiwa anak. Konteksnya dengan tanggung jawab orang tua dalam pendidikan, maka orang tua adalah pendidik pertama dan utama dalam keluarga. Jadi lingkungan keluarga merupakan kondisi yang dapat mempengaruhi perilaku seseorang karena keluarga merupakan lingkungan yang pertama dan utama bagi perkembangan individu. Kondisi keluarga yang harmonis dan perhatian akan mendorong anak giat belajar yang pada akhirnya akan mencapai hasil belajar yang optimal. Sedangkan kondisi keluarga yang kurang harmonis dan tidak dapat perhatian dari orang tua yang kurang mendukung dalam hasil belajar siswa sehingga tidak teralisasikan.

Selain faktor lingkungan keluarga, faktor yang tidak kalah pentingnya yaitu motivasi belajar. Motivasi merupakan serangkaian usaha untuk menyediakan kondisi-kondisi tertentu, sehingga seseorang mau dan ingin melakukan sesuatu (Sardiman, 2011:75). Menurut Eysenck dan kawan-kawan (dalam Slameto, 2003:170) motivasi dirumuskan sebagai suatu proses yang menentukan tingkatan kegiatan serta arah umum dari tingkah laku manusia, merupakan konsep yang berkaitan dengan konsep-konsep yang lain seperti minat, konsep diri, sikap dan sebagainya.
Dalam kegiatan belajar, motivasi memang berperanan penting karena motivasi mempunyai fungsi mendorong timbulnya tingkah laku dan suatu perbuatan, mengarahkan perbuatan untuk mencapai tujuan yang diinginkan dan menggerakkan tingkah laku (Hamalik, 2011:161). Begitu pula dengan motivasi belajar siswa terhadap mata pelajaran akuntansi, yang dapat mempengaruhi hasil belajar siswa itu sendiri. Mata pelajaran akuntansi merupakan mata pelajaran yang perlu banyak latihan dan praktek.

Siswa yang bermotivasi tinggi dalam belajar memungkinkan akan memperoleh hasil belajar yang tinggi pula, artinya semakin tinggi motivasinya, semakin intensitas usaha dan upaya yang dilakukan, maka semakin tinggi hasil belajar yang diperolehnya. Siswa melakukan berbagai upaya atau usaha untuk meningkatkan keberhasilan dalam belajar sehingga mencapai keberhasilan yang cukup memuaskan sebagaimana yang diharapkan. Di samping itu motivasi juga menopang upaya-upaya dan menjaga agar proses belajar siswa tetap jalan. Hal ini menjadikan siswa gigih dalam belajar.

Pada garis besarnya motivasi menentukan tingkat keberhasilan atau kegagalan kegiatan belajar siswa. Pembelajaran yang bermotivasi pada hakikatnya adalah pembelajaran yang sesuai dengan kebutuhan, dorongan, motif, minat yang ada pada diri siswa. Berhasil atau gagalnya dalam membangkitkan dan mendayagunakan motivasi dalam proses pembelajaran berkaitan dengan upaya pembinaan kedisiplinan kelas yang dilakukan oleh pendidik.

\section{Hasil Belajar}

Menurut Rusman (2012:123) hasil belajar adalah sejumlah pengalaman yang diperoleh siswa yang mencakup ranah kognitif, afektif dan psikomotori. Hal tersebut senada dengan pendapat Oemar Hamalik dalam Rusman (2012:123) yang menyatakan bahwa hasil belajar itu dapat terlihat dari terjadinya perubahan dari persepsi dan perilaku, termasuk juga 
perbaikan perilaku. Menurut Sukmadinata (2009:179) hasil belajar bukan hanya berupa penguasaan pengetahuan, tetapi juga kecakapan dan keterampilan dalam melihat, menganalisis dan memecahkan masalah, membuat rencana dan mengadakan pembagian kerja, dengan demikian aktivitas dan produk yang dihasilkan dari aktivitas belajar ini mendapatkan penilaian. Penilaian tidak hanya dilakukan secara tertulis, tetapi juga secara lisan dan penilaian perbuatan.

$$
\text { Dalyono }
$$

mengemukakan faktor-faktor yang menentukan pencapaian hasil belajar yaitu:

a. Faktor Internal (yang berasal dari dalam diri) meliputi:

1. Kesehatan

Kesehatan jasmani dan rohani sangat besar pengaruhnya terhadap kemampuan belajar. Bila seseorang selalu tidak sehat, sakit kepala, demam, pilek, batuk dan sebagainya dapat mengakibatkan tidak bergairah untuk belajar.

2. Inteligensi dan bakat

Seseorang yang memiliki inteligensinya baik pada umumnya mudah belajar dan hasilnya pun cenderung baik. Bakat, juga besar pengaruhnya dalam menentukan keberhasilan belajar.

3. Minat dan motivasi

Minat belajar yang besar cenderung menghasilkan prestasi yang tinggi, sebaliknya minat belajar kurang akan menghasilkan prestasi yang rendah. Motivasi adalah daya penggerak/pendorong untuk melakukan sesuatu pekerjaan. Motivasi yang berasal dari dalam diri (intrinsik) yaitu dorongan yang datang dari hati sanubari, umumnya karena kesadaran akan pentingnya sesuatu. Motivasi yang berasal dari luar (ekstrinsik) yaitu dorongan yang datang dari luar diri (lingkungan), misalnya dari orang tua, guru, teman-teman dan anggota masyarakat. Kuat lemahnya motivasi belajar seseorang turut mempengaruhi keberhasilannya.

4. Cara belajar

Cara belajar seseorang juga mempengaruhi pencapaian hasil belajarnya. Belajar tanpa memperhatikan teknik dan faktor fisiologis, psikologis, dan ilmu kesehatan, akan memperoleh hasil yang kurang memuaskan.

b. Faktor eksternal (yang berasal dari luar diri) meliputi:

\section{Keluarga}

Faktor orang tua sangat besar pengaruhnya terhadap keberhasilan anak dalam belajar. Tinggi rendahnya pendidikan orang tua, besar kecilnya penghasilan, cukup atau kurangnya perhatian dan bimbingan orang tua, rukun atau tidaknya kedua orang tua, akrab atau tidaknya hubungan orang tua dengan anak-anak, tenang atau tidaknya situasi dalam rumah, semuanya itu turut mempengaruhi pencapaian hasil belajar anak.

\section{Sekolah}

Keadaan sekolah tempat belajar turut mempengaruhi tingkat keberhasilan belajar. Kualitas guru, metode mengajarnya, kesesuaian kurikulum dengan kemampuan anak, keadaan fasilitas/perlengkapan disekolah, keadaan ruangan, jumlah murid perkelas, pelaksanaan tata tertib sekolah, dan sebagainya, semua ini turut mempengaruhi keberhasilan belajar anak.

3. Masyarakat

Bila di sekitar tempat tinggal keadaan masyarakatnya terdiri dari orang-orang yang berpendidikan, terutama anakanaknya rata-rata bersekolah tinggi dan moralnya, baik, hal ini akan mendorong anak lebih giat belajar. Tetapi sebaliknya, apabila tinggal di lingkungan banyak anak-anak yang nakal, tidak bersekolah dan pengangguran, hal ini akan mengurangi semangat belajar atau dapat dikatakan tidak menunjang sehingga motivasi belajar berkurang.

4. Lingkungan sekitar

Keadaan lingkungan, bangunan rumah, suasana sekitar, keadaan lalu lintas, iklim dan sebagainya. Misalnya bangunan rumah penduduk sangat rapat, akan menganggu belajar. 
Dan Slameto (2003:54-72) menyatakan faktor-faktor yang mempengaruhi belajar adalah:

1. Faktor intern

a. Faktor jasmaniah yang meliputi kesehatan dan cacat tubuh

b. Faktor psikologis yaitu; inteligensi, perhatian, minat, bakat, motif, kematangan, dan kesiapan

c. Faktor kelelahan

2. Faktor ekstern

a. Faktor keluarga yaitu: cara orang tua mendidik, relasi antaranggota keluarga, suasana rumah, keadaan ekonomi keluarga, pengertian orang tua, dan latar belakang kebudayaan

b. Faktor sekolah yaitu: metode mengajar, kurikulum, relasi guru dengan siswa, relasi siswa dengan siswa, disiplin sekolah, alat pelajaran, waktu sekolah, standar pelajaran di atas ukuran, keadaan gedung, metode belajar, dan tugas rumah.

c. Faktor masyarakat yaitu: kegiatan siswa dalam masyarakat, mass media, teman bergaul, dan bentuk kehidupan masyarakat.

\section{Lingkungan Keluarga}

Soekanto (2004:70) mengatakan lingkungan pertama yang berhubungan dengan anak adalah orang tuanya, saudarasaudarnya serta mungkin kerabat dekatnya yang tinggal serumah. Hal ini sesuai dengan Slameto (2003:61) bahwa keluarga adalah lembaga pendidikan yang pertama dan utama. Keluarga yang sehat besar artinya untuk pendidikan dalam ukuran kecil, tetapi bersifat menentukan untuk pendidikan dalam ukuran besar yaitu pendidikan bangsa, negara dan dunia. Menurut Dalyono (2007:59) keluarga adalah ayah, ibu dan anak-anak serta famili yang menjadi penghuni rumah. Selanjutnya menurut $\mathrm{Ki}$ Hajar Dewantoro dalam Tirtarahardja (2005:168) suasana kehidupan keluarga merupakan tempat sebaik-baiknya untuk melakukan pendidikan individual maupun pendidikan sosial. Keluarga itu tempat pendidikan yang sempurna sifat dan wujudnya untuk melangsungkan pendidikan ke arah pembentukan pribadi yang utuh. Peran orang tua dalam keluarga sebagai penuntun, sebagai pengajar, dan sebagai pemberi contoh.

Menurut Dalyono (2007:59) yang menjadi faktor dalam lingkungan keluarga yang memiliki pengaruh terhadap keberhasilan anak dalam belajar adalah faktor orang tua yang meliputi tinggi rendahnya pendidikan orang tua, besar kecilnya penghasilan, cukup atau kurangnya perhatian dan bimbingan orang tua, rukun atau tidaknya kedua orang tua, akrab atau tidaknya situasi dalam rumah. Dan faktor keadaan rumah yang meliputi ukuran rumah, peralatan untuk belajar dan ruang belajar. Semua itu turut menentukan keberhasilan belajar siswa.

Hal ini sejalan dengan pendapat Slameto (2003:60) yang menyatakan bahwa siswa yang belajar akan menerima pengaruh dari keluarga berupa cara orang tua mendidik, relasi antara anggota keluarga, suasana rumah tangga, keadaan ekonomi keluarga, pengertian orang tua dan latar belakang kebudayaan. Faktorfaktor tersebut apabila dijalan sesuai dengan fungsi dan peranannya masingmasing dengan baik, hal ini akan terciptanya suasana yang nyaman dalam keluarga dan akan mendorong anak untuk lebih giat belajar.

\section{Motivasi Belajar}

Hamalik (2011:158) mengatakan motivasi adalah perubahan energi dalam diri (pribadi) seseorang yang ditandai dengan timbulnya perasaan dan reaksi untuk pencapai tujuan. Menurut Djamarah (2002:114) motivasi sebagai suatu pendorong yang mengubah energi dalam diri seseorang ke dalam bentuk aktivitas nyata untuk mencapai tujuan tertentu. Sedangkan menurut Mc. Donald (dalam Sardiman, 2011:73-74) motivasi adalah perubahan energi dalam diri seseorang yang ditandai dengan munculnya "feeling" dan didahului dengan tanggapan terhadap adanya tujuan. Dari pengertian yang dikemukakan Mc. Donald ini mengandung tiga elemen penting, yaitu: 
a. Bahwa motivasi itu mengawali terjadinya perubahan energi pada diri setiap individu manusia.

b. Motivasi ditandai dengan munculnya rasa "feeling", afeksi seseorang. Dalam hal ini motivasi relevan dengan persoalan-persoalan kejiwaan, afeksi dan emosi yang dapat menentukan tingkah laku manusia.

c. Motivasi akan dirangsang karena adanya tujuan.

Menurut Sardiman (2011:85) fungsi motivasi ada tiga yaitu:

a. Mendorong manusia untuk berbuat, jadi sebagai penggerak atau motor yang melepaskan energi. Motivasi dalam hal ini merupakan motor penggerak dari setiap kegiatan yang akan dikerjakan.

b. Menentukan arah perbuatan, yakni kearah tujuan yang hendak dicapai. Dengan demikian, motivasi dapat memberikan arah dan kegiatan yang harus dikerjakan sesuai dengan tujuannya.

c. Menyeleksi perbuatan, yakni menentukan perbuatanperbuatan apa yang harus dikerjakan yang serasi guna mencapai tujuan, dengan menyisihkan perbuatanperbuatan yang tidak bermanfaat bagi tujuan tersebut.

Sedangkan menurut Hamalik (2011:161) fungsi motivasi adalah:

a. Mendorong timbulnya kelakuan atau suatu perbuatan. Tanpa motivasi maka tidak akan timbul sesuatu perbuatan seperti belajar. b. Motivasi berfungsi sebagai pengarah. Artinya mengarahkan perbuatan kepencapaian tujuan yang diinginkan.

c. Motivasi berfungsi sebagai penggerak.

Djamarah (2002:115-117) mengemukakan macam-macam motivasi yaitu sebagai berikut:

a. Motivasi instrinsik adalah motif-motif yang menjadi aktif atau berfungsinya tidak perlu dirangsang dari luar, karena dalam setiap diri individu sudah ada dorongan untuk melakukan sesuatu.

b. Motivasi ekstrinsik adalah motif-motif yang aktif dan berfungsi karena adanya perangsang dari luar.

Sedangkan menurut Hamalik (2011:162-163) motivasi dapat dibagi menjadi dua yaitu:

a. Motivasi intrinsik adalah motivasi yang tercakup di dalam situasi belajar dan menemui kebutuhan dan tujuan-tujuan murid.

b. Motivasi ekstrinsik adalah motivasi yang disebabkan oleh faktor-faktor dari luar situasi belajar, seperti angka kredit, ijazah, tingkatan hadiah, dan persaingan yang bersifat negatif ialah sarcasm, ridicule, dan hukuman.

Motivasi mempunyai peranan yang strategis dalam aktivitas belajar seseorang, karena dengan adanya motivasi maka seseorang akan belajar dengan sungguhsungguh. Menurut Djamarah (2002:118) prinsip motivasi adalah sebagai berikut:

1. Motivasi sebagai dasar penggerak yang mendorong aktivitas belajar.

2. Motivasi intrinsik lebih utama daripada motivasi ekstrinsik dalam belajar. 
3. Motivasi berupa pujian lebih baik daripada hukuman.

4. Motivasi berhubungan erat dengan kebutuhan dalam belajar.

5. Motivasi dapat memupuk optimisme dalam belajar.

6. Motivasi melahirkan prestasi dalam belajar.

Menurut Dimyati dan Mudjiono (2002:85) motivasi belajar penting bagi siswa yaitu sebagai berikut:

1. Menyadarkan kedudukan pada awal belajar, proses, dan hasil akhir.

2. Menginformasikan tentang kekuatan usaha belajar, yang dibandingkan dengan teman sebaya.

3. Mengarahkan kegiatan belajar.

4. Membesarkan semangat belajar

5. Menyadarkan tentang adanya perjalanan belajar dan kemudian bekerja (disela-selanya adalah istirahat atau bermain) yang bersinambungan, individu dilatih untuk menggunakan kekuatannya sedemikian rupa sehingga dapat berhasil.

Motivasi belajar juga penting diketahui oleh seorang guru (Dimyati dan Mudjiono, 2002:85-86). Pengetahuan dan pemahaman tentang motivasi belajar pada siswa bermanfaat bagi guru, manfaat itu sebagai berikut:

1. Membangkitkan, meningkatkan, dan memilihara semangat siswa untuk belajar sampai berhasil

2. Mengetahui dan memahami motivasi belajar siswa di kelas bermacam ragam.

3. Meningkatkan dan menyadarkan guru untuk memilih satu di antara bermacam-macam peran seperti sebagai penasehat, fasilitator, instruktur, teman diskusi, penyemangat pemberi hadiah, atau pendidik

4. Memberi peluang guru untuk "unjuk kerja" rekayasa pedagogis

Sardiman

(2011:92-95)

mengemukakan beberapa bentuk dan cara untuk menumbuhkan motivasi dalam kegiatan belajar di sekolah, yaitu sebagai berikut:

1. Memberi angka

2. Hadiah

3. Saingan/kompetisi

4. Ego-involvement

5. Memberi ulangan

6. Mengetahui hasil

7. Pujian

8. Hukuman

9. Hasrat untuk belajar

10. Minat

11. Tujuan yang diakui

Menurut Sardiman (2011:83) motivasi yang ada pada diri setiap orang itu memiliki ciri-ciri motivasi sebagai berikut:

a. Tekun menghadapi tugas

b. Ulet menghadapi kesulitan (tidak lekas putus asa)

c. Menunjukkan minat terhadap bermacam-macam masalah

d. Lebih senang bekerja mandiri

e. Cepat bosan pada tugas-tugas yang rutin

f. Dapat mempertahankan pendapatnya (kalau sudah yakin akan sesuatu)

g. Mencari dan memecahkan masalah soal-soal

\section{METODE PENELITIAN}

Penelitian ini merupakan penelitian deskriptif dan kausatif. Populasi dalam penelitian ini adalah siswa kelas $\mathrm{X}$ Pemasaran, $\mathrm{X}$ Administrasi Perkantoran dan $\mathrm{X}$ Akomodasi Perhotelan yang 
mempelajari mata pelajaran akuntansi sebanyak 98 orang. Sedangkan sampel dalam penilitian ini adalah seluruh jumlah populasi. Instrumen penelitian yang digunakan berupa kuesioner atau angket. Sebelum digunakan sebagai alat pengumpulan data penelitian, angket terlebih dahulu di uji cobakan kepada siswa kelas X SMK N 1 Solok Selatan untuk mengukur tingkat validitas dan reliabilitas angket tersebut. Validitas digunakan untuk mengukur sah atau valid tidaknya suatu kuesioner, Ghozali (2011:52). Uji validitas menggunakan Product Moment Correlation. Reliabilitas adalah alat untuk mengukur suatu kuesioner yang merupakan indikator dari variabel atau konstruk, Ghozali (2011:47). Uji reliabilitas menggunakan Cronbach Alpha. Berdasarkan hasil uji coba tersebut, dari 46 pertanyaan semuanya valid dan reliabel untuk digunakan sebagai alat pengumpulan data penelitian.

Teknik analisis data menggunakan analisis deskriptif dan analisis induktif. Analisis deskriptif yang dipakai dalam penelitian ini adalah persentase, rata-rata, standar deviasi, dan TCR. Untuk analisis induktif digunakan analisis regresi berganda. Sebelum dilakukan analisis regresi berganda, terlebih dahulu dilakukan uji asumsi klasik yaitu uji normalitas, uji heteroskedastisitas, dan uji multikolonearitas.

\section{PEMBAHASAN}

Dari hasil pengumpulan data, untuk variabel lingkungan keluarga diperoleh rata-rata 3,51 dengan TCR $70,17 \%$ yang dikategorikan baik. Sementara itu, untuk variabel motivasi belajar diperoleh ratarata 3,67 dengan TCR 73,45 yang dikategorikan baik. Dan untuk hasil belajar diperoleh rata-rata 78,31 yang dapat dikategorikan baik.

Sebelum dilakukan analisis regresi berganda, terlebih dahulu dilakukan uji asumsi klasik yaitu uji normalitas, uji heteroskedastisitas, dan uji multikolonearitas. Uji normalitas Kolmograv Smirnov diperoleh Asymp. Sig. (2-tailed) untuk variabel $\mathrm{X}_{1}=0,365, \mathrm{X}_{2}=$ 0,625 dan Sig $\mathrm{Y}=0,099$. Dengan demikian dapat dinyatakan semua variabel dalam penelitian ini terdistribusi secara normal. Uji heteroskedastisitas dilakukan dengan melihat grafik Plot (scatterplot), jika tidak terdapat pola yang jelas serta titik-titik menyebar di atas dan di bawah angka 0 (nol) pada sumbu Y, maka tidak terjadi heteroskedastisitas. Berdasarkan pengujian yang telah dilakukan bahwa tidak terjadi heteroskedastisitas. Selanjutnya, hasil uji multikolonearitas memperlihatkan bahwa dari variabel $\mathrm{X}_{1}$ dan $\mathrm{X}_{2}$ adalah 1 dengan VIF 1, maka dapat disimpulkan bahwa diantara variabel bebas pada penelitian ini tidak terjadi multikolonearitas.

Setelah dilakukan uji asumsi klasik, maka dilakukan analisis regresi berganda dengan hasil yang dapat dilihat pada tabel 2 berikut ini:

Tabel 2. Rekapitulasi Hasil Analisis Regresi Berganda

\begin{tabular}{lrrr}
\hline \multicolumn{1}{c}{ Variabel Terikat } & B & t & Sig \\
\hline Konstanta & 58,143 & 9,623 & 0,000 \\
Lingkungan Keluarga (X1) & 2,967 & 2,118 & 0,037 \\
Motivasi Belajar (X2) & 2,627 & 2,553 & 0,012 \\
F hitung =5,973 & & & \\
F Signifikan =0,004 & & & \\
R Square =0,114 & & &
\end{tabular}

Dari Tabel 2, dapat dibuat persamaan

$\mathrm{Y}=58,143+2,967 \mathrm{X}_{1}+2,627 \mathrm{X}_{2}+\mathrm{e}$

regresi sebagai berikut: 
Dari persamaan regresi tersebut diketahui nilai konstanta sebesar 58,143 artinya jika lingkungan keluarga (X1) dan motivasi belajar (X2) nilainya adalah 0 , maka hasil belajar (Y) nilainya adalah 58,143 .

Sementara itu, koefisien determinasi berguna untuk menunjukkan seberapa besar kontribusi variabel bebas terhadap variabel terikat. Hasil olahan data diperoleh nilai $\mathrm{R}$ Square 0,114 yang artinya hasil belajar akuntansi siswa sebesar 11,4\% disumbangkan oleh lingkungan keluarga dan motivasi belajar, sedangkan sisanya dipengaruhi oleh faktor lain yang tidak diteliti dalam penelitian ini.

Berdasarkan Tabel 2 dapat dilakukan pengujian hipotesis sebagai berikut:

1. Hipotesis 1

Hipotesis pertama dalam penelitian ini adalah lingkungan keluarga berpengaruh signifikan terhadap hasil belajar akuntansi siswa kelas X SMK N 1 Solok Selatan. Dari tabel 2, dapat dilihat bahwa variabel lingkungan keluarga diperoleh nilai thitung sebesar $2,118>t_{\text {tabel }} 2,000$ dengan nilai signifikan $0,037<\alpha=0,05$, berarti $\mathrm{H}_{\mathrm{a}}$ diterima dan $\mathrm{H}_{0}$ ditolok dengan demikian dapat dikatakan bahwa terdapat pengaruh yang signifikan secara parsial antara lingkungan keluarga terhadap hasil belajar siswa SMK N 1 Solok Selatan.

2. Hipotesis 2

Hipotesis kedua dalam penelitian ini adalah motivasi belajar berpengaruh signifikan terhadap hasil belajar akuntansi siswa kelas X SMK N 1 Solok Selatan. Dari tabel 2, dapat dilihat bahwa variabel motivasi belajar diperoleh nilai $t_{\text {hitung }}$ sebesar 2,553 > $\mathrm{t}_{\text {tabel }} 2,000$ dengan nilai signifikan 0,012 $<\alpha=0,05$, berarti $\mathrm{H}_{\mathrm{a}}$ diterima dan $\mathrm{H}_{0}$ ditolok dengan demikian dapat dikatakan bahwa terdapat pengaruh yang signifikan secara parsial antara motivasi belajar terhadap hasil belajar siswa SMK N 1 Solok Selatan.

3. Hipotesis 3
Hipotesis ketiga adalah lingkungan keluarga dan motivasi belajar siswa berpengaruh signifikan terhadap hasil belajar akuntansi siswa kelas X SMK N 1 Solok Selatan. Uji F dilakukan untuk membuktikan dengan tingkat keberartian tertentu seluruh variabel bebas terhadap variabel terikat. Dari hasil pengolahan data untuk uji $F$ diketahui nilai $F_{\text {hitung }} 5,973>F_{\text {tabel }} 3,10$ dan nilai signifikan $0,004<\alpha=0,05$ yang berarti $\mathrm{H}_{0}$ ditolak dan $\mathrm{H}_{\mathrm{a}}$ diterima. Hal ini menunjukkan bahwa lingkungan keluarga dan motivasi belajar siswa berpengaruh signifikan terhadap hasil belajar akuntansi siswa kelas X SMK N 1 Solok Selatan.

Dari hasil penelitian yang dilakukan di SMK N 1 Solok Selatan terlihat bahwa:

1. Pengaruh lingkungan keluarga dan motivasi belajar siswa terhadap hasil belajar akuntansi siswa kelas X SMK N 1 Solok Selatan.

Berdasarkan analisis data dan pengujian hipotesis yang telah dilakukan diperoleh nilai $\mathrm{F}_{\text {hitung }} 5,973>$ $F_{\text {tabel }} 3,10$ dan nilai signifikan $0,004<\alpha$ $=0,05$. Hal ini menunjukkan bahwa lingkungan keluarga dan motivasi belajar siswa berpengaruh secara signifikan terhadap hasil belajar akuntansi siswa kelas X SMK Negeri 1 Solok Selatan. Semakin baik lingkungan keluarga dan motivasi belajar maka akan semakin baik pula hasil belajar yang diperoleh oleh siswa tersebut, begitu juga sebaliknya jika lingkungan keluarga dan motivasi belajar tidak baik atau kurang baik maka hasil belajar yang diperoleh siswa juga kurang baik atau kurang memuaskan.

Secara keseluruhan lingkungan keluarga yang dimiliki siswa berada pada kategori baik yakni memiliki ratarata TCR sebesar 70,17\%. Hal ini membuktikan bahwa lingkungan keluarga sudah baik dan dapat mempengaruhi hasil belajar siswa. Sedangkan motivasi belajar yang 
dimiliki siswa berada pada kategori baik yakni rata-rata TCR sebesar $73,45 \%$. Hal ini membuktikan bahwa motivasi belajar sudah baik dan mampu mempengaruhi hasil belajar siswa. Secara simultan lingkungan keluarga dan motivasi belajar mempengaruhi hasil belajar sebesar 0,114 atau 11,40\%, sedangkan sisanya 0,886 atau $88,60 \%$ dipengaruhi oleh faktor lain yang tidak diteliti dalam dalam penelitian ini.

Dalyono

(2007:55-60)

mengemukakan faktor-faktor yang menentukan pencapaian hasil belajar yaitu faktor internal (yang berasal dari dalam diri) meliputi kesehatan, inteligensi dan bakat, minat dan motivasi dan cara belajar, sedangkan faktor eksternal (yang berasal dari luar diri) meliputi keluarga, sekolah, masyarakat dan lingkungan sekitar.

Guru memiliki pengaruh dalam meningkatkan hasil belajar siswa. Di dalam kelas guru bertanggung jawab sebagai pengajar dan pengelolah kelas. Sebagai pengajar guru harus dapat bertanggung jawab kepada siswa untuk meningkatkan kualitas pembelajaran yang diterima siswa sehingga dapat meningkatkan hasil belajar siswa.

Dari uraian di atas, dapat disimpulkan bahwa lingkungan keluarga dan motivasi belajar siswa baik secara parsial maupun simultan berpengaruh signifikan terhadap hasil belajar akuntansi siswa.

2. Pengaruh lingkungan keluarga terhadap hasil belajar akuntansi siswa kelas $\mathrm{X}$ SMK N 1 Solok Selatan.

Berdasarkan pengujian hipotesis yang telah dilakukan diperoleh hasil bahwa lingkungan keluarga berpengaruh signifikan dan positif terhadap hasil belajar akuntansi siswa kelas X SMK Negeri 1 Solok Selatan. Hal ini dapat dilihat pada Tabel 4.10 yang menyatakan bahwa $t_{\text {hitung }} 2,118>$ $\mathrm{t}_{\text {tabel }} 2,000$ dan signifikan $0,037<\alpha=$ 0,05 , dan koefisien regresi linear berganda $b=X 1(2,967)$, hal ini berarti bahwa semakin baik lingkungan keluarga maka akan semakin baik pula hasil belajar yang diperoleh oleh siswa, begitu juga sebaliknya apabila lingkungan keluarga tidak baik maka hasil belajar yang diperoleh oleh siswa juga tidak akan baik.

Dari hasil penelitian lingkungan keluarga berada pada kategori baik. Dilihat dari frekuensi lingkungan keluarga siswa kelas X SMK Negeri 1 Solok Selatan yaitu memiliki rata-rata variabel sebesar $70,17 \%$, hal ini berarti lingkungan keluarga berada dalam kategori baik karena berada pada rentang TCR 61\%-80\% (Riduwan, 2010:98). Berdsarkan hasil penelitian di atas, diketahui bahwa lingkungan keluarga berpengaruh positif dan signifikan terhadap hasil belajar akuntansi siswa.

Hasil penelitian ini sesuai dengan penelitian yang dilakukan oleh Nurhasnah (2012) dalam jurnal yang berjudul pengaruh lingkungan keluarga dan efikasi diri terhadap hasil belajar produktif akuntansi siswa program keahlian akuntansi SMK Bukittinggi. Hasil penelitiannya menunjukkan bahwa lingkungan keluarga dan efikasi diri berpengaruh signifikan dan positif terhadap hasil belajar produktif akuntansi siswa PKA SMK Bukittinggi.

3. Pengaruh motivasi belajar siswa terhadap hasil belajar akuntansi siswa kelas X SMK N 1 Solok Selatan.

Berdasarkan pengujian hipotesis yang telah dilakukan diperoleh hasil bahwa motivasi belajar berpengaruh signifikan dan positif terhadap hasil belajar akuntansi siswa kelas X SMK Negeri 1 Solok Selatan. Hal ini dapat dilihat pada Tabel 4.10 yang menyatakan bahwa $t_{\text {hitung }} 2,553>t_{\text {tabel }}$ 2,000 dan signifikan $0,012<\alpha=0,05$, dan koefisien regresi linear berganda $b=X 2 \quad(2,627)$, hal ini berarti bahwa semakin baik motivasi belajar maka akan semakin baik pula hasil belajar yang diperoleh oleh siswa, begitu juga sebaliknya apabila motivasi belajar tidak baik maka hasil belajar yang 
diperoleh oleh siswa juga tidak akan baik.

Dari hasil penelitian motivasi belajar siswa berada pada kategori baik, dilihat dari frekuensi motivasi belajar siswa kelas $\mathrm{X}$ SMK Negeri 1 Solok Selatan yaitu rata-rata variabelnya sebesar 73,45\%. Hal ini berarti menunjukkan bahwa motivasi belajar berada dalam kategori baik karena berada pada rentang TCR 61\%-80\% (Riduwan, 2010:98). Hasil penelitian ini membuktikan bahwa motivasi belajar berpengaruh positif dan signifikan terhadap hasil belajar akuntansi siswa.

Hasil penelitian ini sesuai dengan penelitian yang dilakukan oleh Andartari (2012) dalam jurnal yang berjudul pengaruh kemampuan intelektual (IQ) dan motivasi belajar terhadap hasil belajar siswa pada mata pelajaran akuntansi pada SMA Labschool Rawamangun. Hasil penelitiannya menunjukkan bahwa kemampuan intelektual dan motivasi belajar terdapat berpengaruh signifikan terhadap hasil belajar siswa pada mata pelajaran akuntansi.

\section{PENUTUP}

\section{Kesimpulan}

Berdasarkan hasil penelitian dan pembahasan dapat disimpulkan bahwa:

1. Lingkungan keluarga berpengaruh positif dan signifikan terhadap hasil belajar akuntansi siswa kelas X SMK Negeri 1 Solok Selatan. Dimana diperoleh nilai $t_{\text {hitung }}$ sebesar 2,118 > $\mathrm{t}_{\text {tabel }}$ sebesar 2,000 dan nilai signifikan $0,037<\alpha=0,05$ berarti $\mathrm{H}_{\mathrm{a}}$ diterima dan $\mathrm{H}_{0}$ ditolok.

2. Motivasi belajar siswa berpengaruh positif dan signifikan terhadap hasil belajar akuntansi siswa kelas X SMK Negeri 1 Solok Selatan. Dimana diperoleh nilai $t_{\text {hitung }}$ sebesar 2,553 > $\mathrm{t}_{\text {tabel }}$ sebesar 2,000 dan nilai signifikan $0,012<\alpha=0,05$ berarti $\mathrm{H}_{\mathrm{a}}$ diterima dan $\mathrm{H}_{0}$ ditolok.

3. Lingkungan keluarga dan motivasi belajar secara simultan berpengaruh signifikan terhadap hasil belajar akuntansi siswa kelas X SMK Negeri 1 Solok Selatan. Dimana diperoleh nilai $F_{\text {hitung }}$ sebesar 5,973 $>F_{\text {tabel }}$ sebesar 3,10 dan nilai signifikan 0,004 $<\alpha=0,05$. Hal ini berarti $\mathrm{H}_{\mathrm{a}}$ diterima dan $\mathrm{H}_{0}$ ditolok.

\section{Saran}

Berdasarkan hasil penelitian, penulis mengemukakan saran yang diharapkan dapat bermanfaat dalam meningkatkan hasil belajar akuntansi siswa yang ditujukan kepada:

1. Bagi guru

Dalam meningkatkan mutu pendidikan dan kelancaran proses belajar mengajar seorang guru hendaknya ikut aktif dalam membantu memberikan informasi tentang bagaimana menimbulkan minat, mencari dan memecahkan soal-soal, cara mencapai hasil belajar yang optimal serta membangkitkan motivasi belajar siswa terhadap mata pelajaran akuntansi dengan menjelaskan kepada siswa bahwa akuntansi bermanfaat bagi dirinya pada saat ini maupun pada saat mendatang. Hal ini dapat dilakukan dengan melaksanakan proses pembelajaran mengajar yang efektif dan efisien, misalnya dengan menggunakan media power poin untuk menyajikan aktifitas pembelajaran yang menarik dan menyenangkan.

2. Bagi siswa

Siswa harus mempunyai pemahaman mengenai motivasi belajar, yaitu dengan cara berusaha untuk menyenangi materi akuntansi dan memperhatikan pada saat guru menjelaskan serta tidak cepat menyerah apabila menemukan kesulitan dalam belajar. Karena apabila motivasi belajar tinggi, maka hasil belajar yang diperoleh akan semakin meningkat. Siswa juga harus membina hubungan baik dan berusaha dekat dengan keluarga serta menumbuhkan sikap saling mengerti, saling membantu dan saling tenggang 
rasa antar sesama anggota keluarga. Apabila hubungan dengan keluarga terjalin baik, maka akan tumbuh semangat untuk belajar dan berusaha membuat keluarga bangga dengan apa yang kita capai.

3. Bagi orang tua siswa

Orang tua sebagai pemegang peran utama dalam sebuah keluarga diharapkan mampu melaksanakan fungsi-fungsi keluarga dengan baik serta menciptakan suasana rumah atau iklim keluarga yang nyaman sehingga dapat tercipta lingkungan keluarga yang serasi, selaras dan kondusif. Karena terbukti bahwa lingkungan keluarga memiliki pengaruh terhadap hasil belajar yang diperoleh siswa. Suasanah rumah yang baik akan memicu semangat siswa untuk belajar. Penulis menyarankan agar orang tua dapat memperhatikan dan mengembangkan sikap belajar anaknya kearah yang lebih baik, dengan selalu menciptakan susana rumah yang nyaman dan membina hubungan yang harmonis dengan anaknya, artinya orang tua harus mengerti dan memahami perbedaan individu maupun potensi yang dimiliki anaknya.

\section{DAFTAR PUSTAKA}

10.22202/economica.2014.v2.i2.221

Arikunto, Suharsimi. 2002. Prosedur Penelitian Suatu Pendekatan Praktik. Jakarta: Rineka Cipta

- 2006. Prosedur Penelitian Suatu Pendekatan Praktik. Jakarta: Rineka Cipta

2010. Prosedur Penelitian Suatu Pendekatan Praktik. Jakarta: Rineka Cipta

Andartari, dkk. Jurnal. 2012. Pengaruh Kemampuan Intelektual (IQ) dan Motivasi Belajar terhadap Hasil Belajar Siswa pada Mata Pelajaran Akuntansi pada SMA Labshool Rawamangu, volume, 1,
18. Diakses tanggal 5 september 2013.

Dalyono, M. 2007. Psikologi Pendidikan. Jakarta: Rineka Cipta

Djamarah,Syaiful Bahri. 2002. Psikologi Belajar. Jakarta: Rineka Cipta

. 2004. Pola Komunikasi Orang Tua dan Anak dalam Keluarga. Jakarta: Rineka Cipta

Dimyati dan Mudjiono. 2002. Belajar dan Pembelajaran. Jakarta: RhinekaCipta

Ghozali, Imam. 2011. Aplikasi Analisis Multivariate dengan Program IBM SPSS 20. Semarang: Badan Penerbit Universitas Diponegoro.

Hamalik, Oemar. 2011. Proses Belajar Mengajar. Jakarta: Bumi Aksara

Idris. 2010. Aplikasi Model Analisis Data Kuantitatif dengan Program SPSS. Padang: FE UNP

Irianto, Agus. 2010. Statistik Konsep Dasar, Aplikasi dan Pengembangannya. Jakarta: Kencana

Niretla S, Elvida. Skripsi 2011. Pengaruh leverge, profitabilitas, ukuran perusahaan, umur perusahaan dan konsentrasi kepemilikan pihak luar terhadap ketepatan waktu penyampaian pelaporan keuangan. (perusahaan manufaktur yang terdaftar di BEI 2006-2009). Padang: FE UNP

Nurhasnah. Jurnal. 2012. Pengaruh Lingkungan Keluarga dan Efikasi Diri terhadap Hasil Belajar Produktif Akuntansi Siswa PKA SMK Bukittinggi. Diakses tanggal 5 september 2013.

Riduwan. 2010. Belajar Mudah Penelitian untuk Guru, Karyawan, dan Peneliti Pemula. Bandung: Alfabeta

Rusman. 2012. Belajar dan Pembelajaran Berbasis Komputer. Bandung: Alfabeta.

Sabri, Ahmad. 2005. Strategi Belajar Mengajar dan Micro Teaching. Jakarta: Quantum Teaching 
Sardiman. 2011. Interaksi dan Motivasi Belajar Mengajar. Jakarta: Rajawali Pers.

Slameto. 2003. Belajar dan Faktor-faktor yang Mempengaruhinya. Jakarta: Rineka Cipta

Soekanto, $\quad$ Soerjono.2004.Sosiologi Keluarga tentang Ikhwal Keluarga, Remaja, dan Anak.Jakarta: Rineka Cipta 